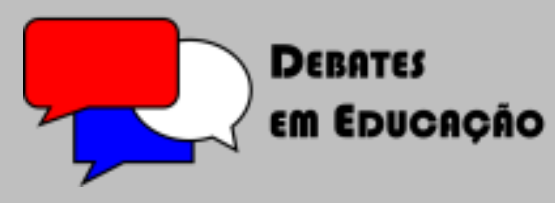

ISSN: $2175-6600$

Vol. 9 | №. 18 | Mai./Ago. | Ano 2017

Nathália Rosa Santos
Universidade Estadual do Sudoeste da Bahia
(UESB)
nathinharosa@hotmail.com

Obertal da Silva Almeida

Universidade Estadual do Sudoeste da Bahia

(UESB)

oalmeida@uesb.edu.br

Matheus Saloes Freitas

Universidade Estadual do Sudoeste da Bahia

(UESB)

msaloes@yahoo.com.br

Nádia Amorim Pereira

Universidade Estadual do Sudoeste da Bahia

(UESB)

nadhyaamorim@yahoo.com.br

\section{INTERVENÇÕES DIDÁTICAS DO PIBID NO PROCESSO DE ENSINO E APRENDIZAGEM DE BIOLOGIA NO COLÉGIO ESTADUAL ALFREDO DUTRA}

\section{RESUMO}

O objetivo deste trabalho é descrever as intervenções didáticas desenvolvidas no âmbito do Programa Institucional de Bolsas de Iniciação a Docência em três turmas de $1^{\circ}$ ano do ensino médio no Colégio Estadual Alfredo Dutra. Os dados foram analisados a partir de 9 atividades que promoveram a participação e envolvimento dos alunos ao estimular suas habilidades, aproximando teoria e prática a partir da investigação, experimentação, construção de modelos didáticos e sequência didática. O dinamismo que o Programa Institucional de Bolsas de Iniciação a Docência trouxe às atividades propostas deu um suporte ao ensino dos conteúdos, foi relevante para o desenvolvimento de aulas mais interativas na construção do conhecimento e foi importante tanto para os alunos quanto para o professor supervisor e os bolsistas de iniciação a docência, pois houve articulação de várias faces do ensino e da aprendizagem.

Palavras-chave: Intervenções didáticas. PIBID. Biologia.

\section{EDUCATIONAL INTERVENTIONS PIBID IN THE TEACHING AND LEARNING BIOLOGY IN THE STATE COLLEGE ALFREDO DUTRA}

\begin{abstract}
The aim of this study is to describe the educational interventions developed within Institutional Program for Initiation to Teaching Scholarship in three groups of 1st year of high school in the State College Alfredo Dutra. Data were analyzed from 9 activities that promoted the participation and involvement of students to stimulate their skills, approaching theory and practice from the research, experimentation, construction of teaching models and instructional sequence. The dynamism that Institutional Program for Initiation to Teaching Scholarship brought to proposed activities gave a support to the teaching of content was relevant to the development of more interactive lessons in constructing knowledge and it was important for both the students and the supervising teacher and Initiation to teaching scholarship, as there was articulation of various faces of teaching and learning.
\end{abstract}

Keywords: Educational interventions. PIBID. Biology.

DOI: $10.28998 / 2175-6600.2017 v 9 n 18 p 136$ 


\section{INTRODUÇÃO}

No ensino de Biologia ainda é muito comum os conteúdos serem ensinados principalmente de forma expositiva, onde os alunos são meros ouvintes de aulas ministradas com base, na maioria das vezes, nos livros didáticos. Segundo Caon (2005) esse é um comodismo do ensino tradicional, onde o conhecimento está centrado no professor e este o transmite como informação, não se preocupando se houve ou não aprendizagem.

Pela praticidade de ministração, aulas teóricas expositivas são muito utilizadas pelos professores de Biologia, dessa forma os alunos são levados a memorizar conceitos e termos complexos, apresentando dificuldades em assimilar os conteúdos e tornando-se desmotivados em relação aos mesmos.

Sendo um dos objetivos do trabalho do professor proporcionar o ensino da melhor forma possível, tentando atingir a aprendizagem significativa do aluno, é imprescindível utilizar diferentes estratégias metodológicas, recursos e/ou atividades alternativas de caráter inovador, na construção do conhecimento. Ausubel (2003) considera a aprendizagem significativa aquela em que os conhecimentos prévios dos alunos são levados em consideração para se construir estruturas mentais, capaz de interpretar e dar significado à novos conceitos.

Segundo Aquino Filho, Machado e Amaral (2015), para que as estratégias didáticas (mecanismos que vão auxiliar no processo de ensino e aprendizagem) sejam significativas é indispensável considerar o conhecimento prévio do aluno.

A escolha de uma estratégia também vai depender do conteúdo abordado e de seus objetivos, da turma, do tempo e recursos disponíveis.

$\mathrm{Na}$ abordagem dos conteúdos de Biologia as atividades ou aulas práticas podem ser muito utilizadas e estas não precisam ser necessariamente desenvolvidas em laboratórios. Se bem planejadas e elaboradas podem ser um instrumento eficiente para o ensino e aprendizagem de certos conteúdos. Ressalta-se que independentemente da modalidade de aula a ser utilizada é importante que sejam planejadas na busca de se ter uma maior participação do aluno, aproximando-o do conteúdo de forma ativa.

Uma das políticas públicas que veio na intenção de somar esforços também nessa direção foi a implementação do Programa Institucional de Bolsas de Iniciação a Docência (PIBID). Este programa foi criado em 2007 pelo Ministério de Educação e Cultura (MEC) e financiado pela Coordenação de Aperfeiçoamento de Pessoal de Nível Superior (CAPES). O Programa trouxe uma nova perspectiva para a educação básica e estudantes de 
licenciaturas. São concedidas bolsas a estudantes de licenciaturas, que participam de projetos de iniciação a docência que são desenvolvidos por universidades em conjunto com escolas da educação básica (BRASIL, 2008).

A partir das intervenções do PIBID na escola, os alunos têm a oportunidade de conhecer novas formas de lidar com os conteúdos da disciplina de Biologia. A prática aliada à teoria em diferentes metodologias realizadas pelos bolsistas do PIBID e professor regente instigam a participação dos alunos e a compreensão dos conteúdos pelos mesmos de forma diferenciada. Professores são estimulados a utilizarem as propostas didáticas que dão grande suporte no processo de ensino-aprendizagem (RAUSCH; FRANTZ, 2013; ROSA; MATTOS, 2013).

As ações do PIBID se subdividem em diferentes áreas das licenciaturas, e na Universidade Estadual do Sudoeste da Bahia/Campus de Itapetinga-BA existe implantado desde 2014 o subprojeto de Biologia intitulado: "Interface didático-pedagógica entre a Universidade e a Escola no contexto do ensino de Biologia", que tem como objetivo a complementação na formação do licenciando em Ciências Biológicas, aperfeiçoando a prática pedagógica a partir da inserção de novos experimentos educacionais que promovam a construção do conhecimento, investigando e refletindo sobre as contribuições de diferentes metodologias de ensino para a aprendizagem nessa modalidade (VIANA et al., 2016).

O subprojeto tem realizado intervenções didáticas em dois colégios de ensino médio do município de Itapetinga-BA, o Colégio Estadual Alfredo Dutra (CEAD) e o Colégio Modelo Luís Eduardo Magalhães (CMLEM). Em um deles (CEAD) funciona a educação em tempo integral, onde os alunos têm as disciplinas básicas no turno matutino e disciplinas complementares no turno vespertino. A disciplina Educação Científica vem a ser uma complementação à disciplina de Biologia e a partir da implementação do PIBID com o subprojeto, bolsistas realizaram diferentes atividades com os alunos.

Neste contexto o presente trabalho tem como objetivo descrever as atividades desenvolvidas no âmbito PIBID no Colégio Estadual Alfredo Dutra localizado no município de Itapetinga-BA. 


\section{METODOLOGIA}

\subsection{Tipos de Pesquisa}

Esta pesquisa se classifica como exploratória e tem sua natureza qualitativa. A pesquisa exploratória visa proporcionar maior familiaridade com o problema com vistas a torná-lo explícito ou a construir hipóteses (SILVA; MENEZES, 2005). As mesmas autoras dizem que a pesquisa de natureza qualitativa não requer o uso de métodos e técnicas estatísticas.

\subsection{Local e realização das intervenções}

No período da execução das atividades o subprojeto constava com uma equipe de 15 componentes, sendo um coordenador, dois professores supervisores, 10 bolsistas de Iniciação a Docência (ID) ${ }^{1}$, uma professora colaboradora e um licenciando voluntário. Destes, cinco bolsistas atuavam no Colégio Estadual Alfredo Dutra, juntamente com um professor supervisor que é professor regente do colégio.

Neste trabalho serão descritas intervenções didáticas desenvolvidas e executadas a partir da implementação do PIBID com o subprojeto de Biologia no Colégio Estadual Alfredo Dutra, município de Itapetinga-BA em três turmas de $1^{\circ}$ ano do ensino médio.

\section{RESULTADOS E DISCUSSÃO}

\subsection{Intervenções no ambiente escolar}

O presente trabalho traz a descrição de intervenções didáticas que foram realizadas em turmas de $1^{\circ}$ Ano do ensino médio do Colégio Estadual Alfredo Dutra no município de Itapetinga-BA. Foram realizadas oito atividades as quais foram intituladas de: o que tem dentro da caixa?; experimento de Redi; montagem de moléculas; compostos orgânicos com músicas; DNA em origami; osmose em célula vegetal; protótipo de célula animal e sequência didática: divisão celular.

\footnotetext{
1 O bolsista de ID tem o papel importante no acompanhamento das atividades de ensino, e essa participação irá contribuir substancialmente no processo de formação acadêmica fortalecendo ainda mais a identidade docente.
} 
Todas as intervenções foram realizadas seguindo a seguinte ordem: observação da explanação do conteúdo pelo professor regente, em seguida um planejamento com base no conteúdo, elaboração do plano de aula da intervenção e posteriormente sua implementação.

\subsubsection{O que tem dentro da caixa?}

Essa atividade foi desenvolvida a partir do conteúdo "A origem da Biologia e as bases do pensamento científico" e teve como objetivo demonstrar as etapas da metodologia científica formulando e testando hipóteses a partir de objetos que se encontravam dentro de uma caixa fechada.

Após o professor regente abordar sobre o conteúdo teórico, os bolsistas de ID distribuíram livros aos alunos que estavam acomodados em grupos, para que estes pudessem ler um pouco sobre diferentes cientistas e seus experimentos científicos, evidenciando o uso de várias hipóteses para se chegar a uma conclusão. A atividade foi desenvolvida na biblioteca do colégio e a sua duração foi de duas horas/aula.

Os alunos manipularam a caixa fechada num processo de investigação, apresentando hipóteses para descobrir quais objetos se encontravam dentro da mesma. Somente perguntas relacionadas à composição e uso dos possíveis objetos eram direcionadas ao professor, cujas respostas eram apenas "sim" e "não". Desta forma, os alunos foram chegando à conclusão sobre quais objetos poderiam estar dentro da caixa.

O professor retomou ao conteúdo teórico enfatizando a importância de todas as hipóteses de um experimento para se chegar a uma conclusão mais objetiva. Os alunos foram avaliados por meio da participação na discussão acerca do assunto.

A atividade prática apresentou-se interessante por promover a participação de todos os alunos, aguçando a curiosidade dos mesmos e a investigação na busca em descobrir os objetos contidos na caixa. Sobre a perspectiva investigativa, Souza Junior e Coelho (2013) dizem que os alunos desenvolvem habilidades sobre a cultura científica e resolvem problemas com etapas estruturadas, buscam evidências que sustentem as ideias, levantam hipóteses que explicam o fenômeno, elaboram conclusões e relatam os resultados.

O ponto bastante importante sobre esta atividade é que ela forneceu aos alunos oportunidade para o desenvolvimento de habilidades reflexivas na construção do conhecimento científico no ensino de Biologia. Ressalta-se que a atividade marcou o início do envolvimento dos alunos com a educação científica. 


\subsubsection{Experimento de Redi}

Para esta atividade o professor fez uma breve explicação sobre as teorias biogênese e abiogênese, e em seguida solicitou que os alunos formassem grupos de aproximadamente cinco integrantes. Feito isso, explicou que o objetivo desta atividade prática seria reproduzir o experimento do cientista Francesco Redi, a fim de comprovar a teoria da biogênese. Esta prática foi desenvolvida no laboratório do colégio, onde foram preparadas amostras com quatro pedaços de carne em quatro frascos transparentes, dois deles cobertos com gaze e dois sem gaze (Figura 1).

Figura 1 - Amostras de carne em frascos.

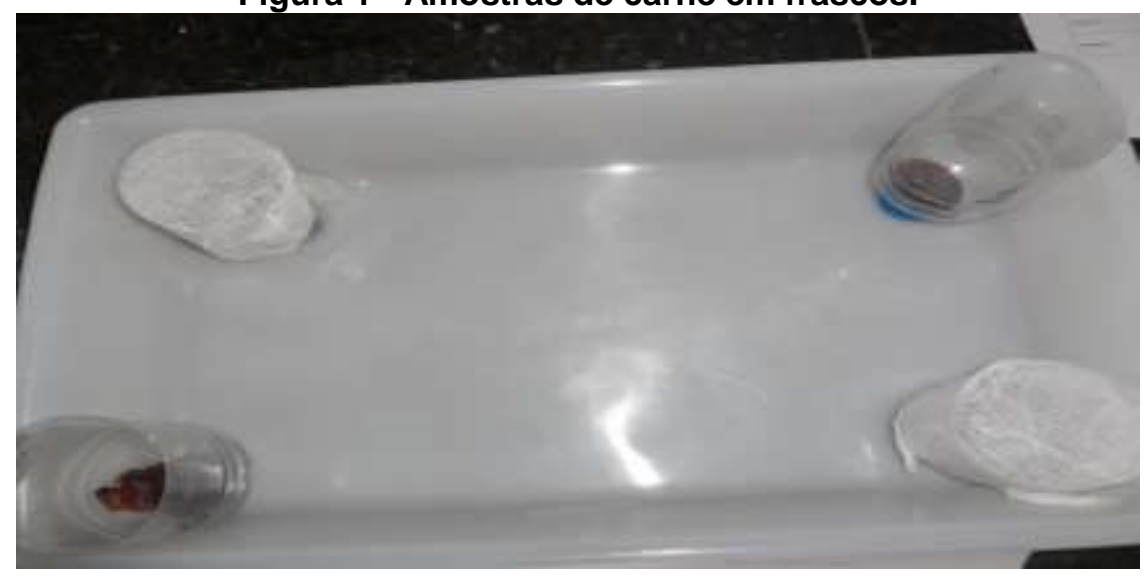

Fonte: Dados da pesquisa.

Salienta-se que as quatro amostras foram únicas para toda a turma, ou seja, somente um experimento foi montado. Cada grupo recebeu uma planilha para registrar as alterações observadas. O período de realização da atividade foram três horas/aula.

Os alunos observaram as amostras durante uma semana, acompanhados de bolsistas de ID. A cada dia um representante de cada grupo comparecia ao laboratório, observava e registrava na planilha as alterações do experimento. Dessa forma, esta atividade se caracteriza como uma atividade experimental demonstrativa, na qual segundo Araújo e Abib (2003), o professor monta o experimento e os alunos observam os fenômenos ocorridos, podendo registrar por escrito o que foi observado.

Esperava-se que apenas nos frascos sem gaze surgissem larvas, no entanto em todos os frascos foi constatada a presença de larvas. Com este resultado foram levantadas hipóteses para possíveis explicações, aguçando o senso de investigação dos alunos. Foi discutido que a possível explicação para tal ocorrido foi que moscas menores puderam passar pelos espaços contidos na gaze. Esta discussão levou a afirmação de que se faz necessário repetir um experimento várias vezes para obter o resultado esperado. Para a 
avaliação o professor solicitou aos alunos um relatório ao final desta prática para apresentarem os resultados.

Essa atividade vem ratificar o que diz a literatura em relação à importância da utilização da atividade experimental no ensino. Segundo Oliveira (2012) a atividade experimental quando atrelada às aulas teóricas, é de suma importância no ensino básico, pois assim o professor estimula o aluno a pensar (imaginar) utilizando uma parte do cérebro que antes era inativo.

Alguns estudos disponíveis na literatura ressaltam também o frequente interesse dos alunos por atividades dessa natureza, bem como relatos de professores sobre relevância da prática experimental na escola como instrumento para a aprendizagem de ciências e biologia (BEREZUK; INADA, 2010; ANDRADE; MASSABNI, 2011).

\subsubsection{Montagem de moléculas}

A prática "montagem de moléculas" foi desenvolvida no laboratório do colégio e teve como objetivo possibilitar aos alunos a compreensão de como os átomos se unem formando moléculas. Com duração de duas horas/aula o desenvolvimento desta atividade foi iniciado pelo professor com uma explicação sobre a definição e constituição de moléculas orgânicas e inorgânicas. Em seguida o professor montou uma molécula utilizando o kit molecular de química, mostrando esferas coloridas que correspondiam aos átomos de Carbono, Hidrogênio, Oxigênio e Nitrogênio; e bastões de duas cores diferentes que simbolizavam as ligações duplas e simples.

O professor exemplificou no quadro algumas moléculas (água, dióxido de carbono, gás oxigênio, gás hidrogênio, amônia e aminoácido) com suas ligações e propôs que os alunos construíssem as fórmulas moleculares com o kit (Figura 2).
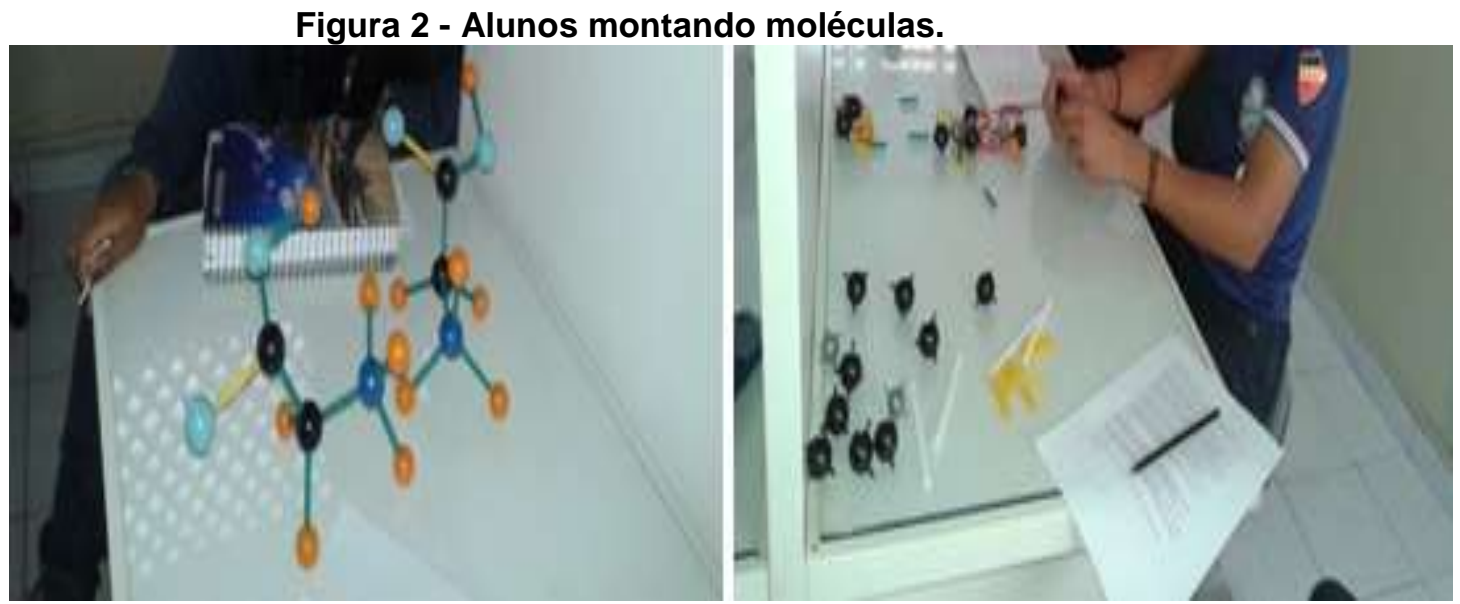

Fonte: Dados da pesquisa. 
Os bolsistas de ID observaram a execução da atividade e sempre que necessário tiravam dúvidas dos alunos de forma individual. Os alunos tiveram um pouco de dificuldade em entender as ligações feitas por diferentes átomos, pois ainda não tinham estudado o conteúdo de ligações químicas. Com isso o professor interrompia e explicava como seria a ligação correta. Dessa forma os alunos se esforçaram, refazendo as moléculas sempre que erravam e assim iam se apropriando do conteúdo.

A realização desta atividade auxiliou os alunos na compreensão e reflexão da estrutura de moléculas orgânicas. De acordo Campos et al. (2014), os alunos quando manipulam e formam protótipos de moléculas, podem perceber os conteúdos, e por se tratar de um material com três dimensões é possível conhecer o número de ligações de cada átomo.

A avaliação dos alunos foi feita por meio da participação direta na atividade e percebeu-se o envolvimento bem ativo dos alunos, com bastante curiosidade para compreenderem a união dos átomos na formação das moléculas.

\subsubsection{Compostos orgânicos com músicas}

Esta atividade teve como objetivo potencializar o processo de aprendizagem acerca de alguns compostos orgânicos com a utilização de músicas. Inicialmente o professor explanou sobre o conteúdo compostos orgânicos e entregou para cada aluno três cópias de letras de músicas sobre os compostos, de autoria de um professor de Biologia, Paulo Alexandre. As músicas tinham os seguintes títulos: "A turma dos lipídios", "Carboidrato que é açúcar" e "As proteínas e as enzimas".

Os alunos fizeram a leitura de cada letra a fim de associarem os conceitos encontrados na música com os que foram explanados pelo professor. Foi utilizada uma TV pen drive da escola como recurso didático para reproduzir as melodias, as quais foram cantadas por alunos e bolsistas de ID acompanhados do professor.

O período de realização da atividade foi de duas horas/aula. A mesma consistiu em uma atividade simples, de baixo custo, havendo compreensão de conceitos sobre compostos orgânicos e trazendo uma dinâmica envolvente e interativa em relação aos alunos, professor e bolsistas de ID.

A receptividade foi boa e todos os alunos demonstraram entusiasmo em aprender as letras das músicas de forma descontraída. Segundo Barros, Zanella e Araújo-Jorge (2013), a facilidade de assimilação da música pelas pessoas faz esse recurso ser associado com o conteúdo disciplinar de maneira prazerosa. E Bertoncello e Santos (2002), pontuam 
que a utilização de música é uma atividade satisfatória por facilitar a concentração e absorção das ideias presente na letra.

\subsubsection{DNA em origami}

Para esta atividade foi empregado um modelo didático tridimensional feito pela técnica de origami, numa proposta de que os alunos pudessem visualizar a estrutura de uma molécula de DNA.

Após breve explicação acerca da estrutura da dupla hélice e pareamento das bases nitrogenadas de uma molécula de DNA, esta atividade foi executada da seguinte maneira: inicialmente foram entregues individualmente aos discentes folhas de oficio com medidas especificas e lápis coloridos, os quais deveriam observar a montagem feita pelos bolsistas e professor supervisor, do passo a passo da construção de um protótipo de uma molécula de DNA por meio do emparelhamento específico das bases nitrogenadas em função do número de pontes de hidrogênio entre as bases (Adenina com Timina, formando duas pontes de hidrogênio e Citosina com Guanina com três pontes de hidrogênio) salientando que as fitas são antiparalelas, enquanto uma fita está em sentido 5'-3' a outra está no sentido 3'- 5'. A atividade foi feita com materiais de baixo custo e fácil acesso na intenção de subsidiar a realização da mesma prática em qualquer escola pública.

A realização da atividade de construção de molécula de DNA foi feita com a utilização de uma folha de papel ofício A4. Foram dadas as medidas individualmente para cada aluno para os traçados que dariam origem aos nucleosídios e a base nitrogenada respeitando os pares de complementaridade entre as mesmas, posteriormente começa a dobradura e a molécula em sua forma helicoidal começa a se formar conforme ilustrado na Figura 3.

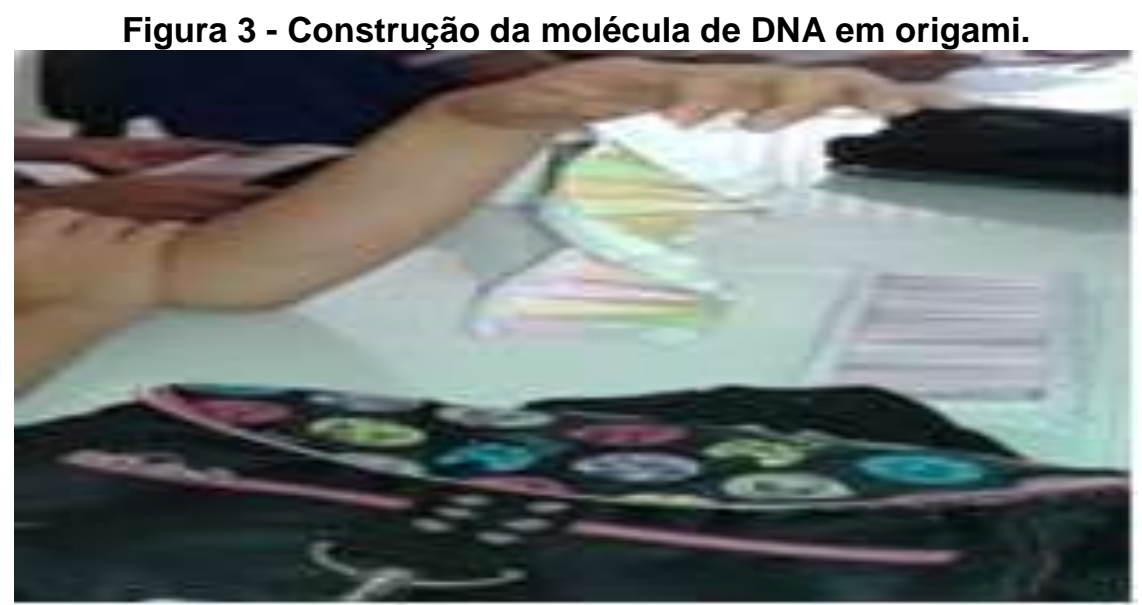

Fonte: Dados da pesquisa 
Esta atividade demandou um tempo de quatro horas/aula e foi observado que alguns alunos apresentaram dificuldade no manuseio da régua para traçar as medidas propostas e em compreender como se dá o pareamento entre as bases, tornando o desenvolvimento da atividade um pouco complexo. Porém, para sanar essa dificuldade, os bolsistas de ID acompanharam os alunos em toda a confecção do modelo e o professor sempre respondia aos questionamentos e dúvidas referente a estrutura da molécula de DNA.

Ainda que tenham tido alguma dificuldade, ressalta-se que cada aluno confeccionou sua própria molécula de DNA. Amorim (2013) enfatiza que a construção do modelo pelos próprios alunos tem um grande significado no aprendizado, pois contribui para maior assimilação do tema estudado e torna o aprendizado mais instigante.

As atitudes dos estudantes em relação a atividade realizada foram satisfatórias, pois teve um número considerável de alunos presentes no início do ano letivo, e não estava sendo contabilizada a presença dos alunos por se tratar de uma disciplina nova, a Educação Científica, que acontecia em horário especial e ainda assim os alunos compareciam a escola demonstrando interesse nas aulas e relataram que alunos de outras séries queriam participar das aulas.

Esse comportamento é interessante e vem refletir o efeito da atividade implementada e conforme Cavalcante e Silva (2008, p.2), "os modelos didáticos (ou pedagógicos) permitem a experimentação, o que, por sua vez, conduzem os estudantes a relacionar teoria (leis, princípios, etc.) e a prática (trabalhos experimentais)”, o que lhes propiciará condições para a compreensão dos conceitos, do desenvolvimento de habilidades, competências e atitudes, contribuindo, também, para reflexões sobre o mundo em que vivem.

\subsubsection{Osmose em célula vegetal}

A turma foi divida em grupos de três membros para o desenvolvimento desta atividade prática experimental, que teve como objetivo contribuir para uma melhor compreensão do conteúdo osmose. Um roteiro de atividade com os procedimentos a serem seguidos foi entregue aos alunos pelos bolsistas de ID. Após o professor regente ler 0 roteiro em voz alta explicando detalhadamente, distribui-se para cada grupo os materiais, a saber: pimentão, bisturi, sal, 03 placas de Petri, 01 béquer com água filtrada e 01 colher de chá.

Cada grupo cortou 09 filetes de pimentão e colocou 03 em cada placa de Petri, acrescentando água até cobri-los (Figura 4). Em seguida adicionou-se 01 colher de chá de 
sal em uma placa, 02 colheres de chá em outra placa e a terceira permaneceu somente com a água. Esperaram um período de 40 minutos e então os alunos observaram diferentes curvaturas nos filetes de pimentão, devido entrada ou saída de água nas células do vegetal. Ao final, com auxílio dos bolsistas de ID, os alunos pesquisaram no livro didático sobre o assunto para que pudessem registrar em forma de um relatório o que foi observado. A prática durou duas horas/aula e os alunos foram avaliados a partir da participação e por meio do relatório prático.
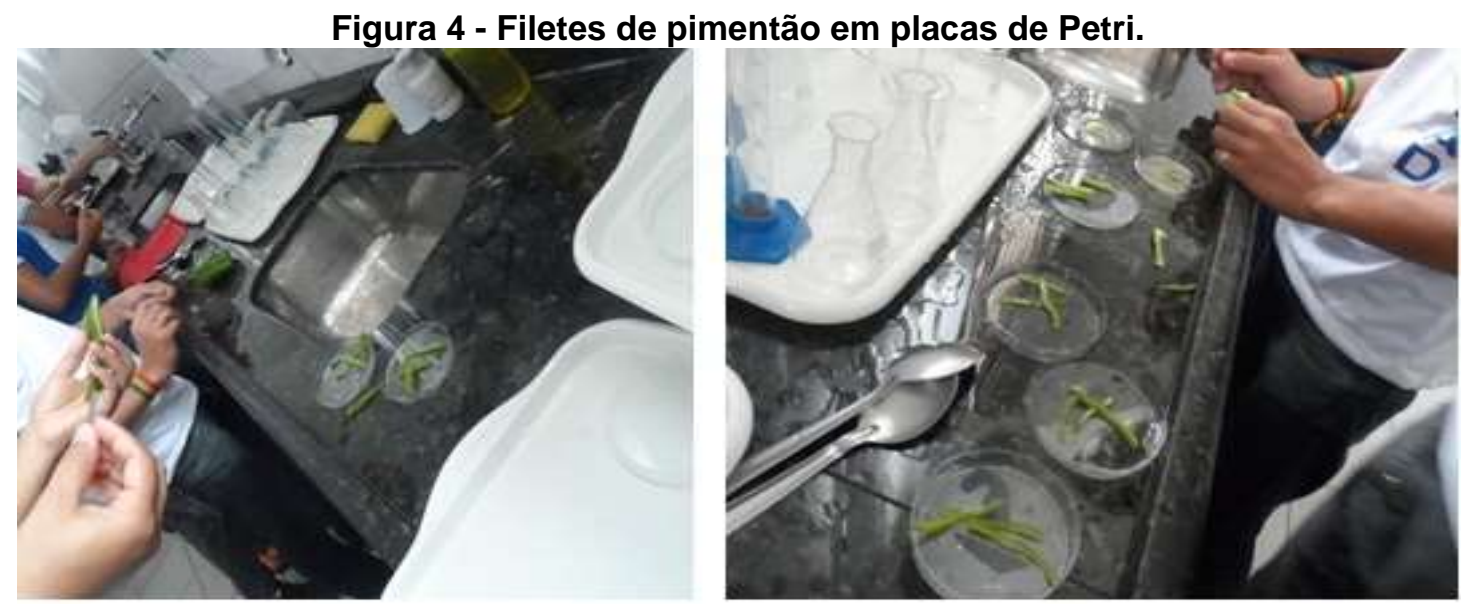

Fonte: Dados da pesquisa

Devido ao curto espaço de tempo, o espaço disponível do laboratório esta atividade foi realizada nos moldes da atividade experimental classificada por Araújo e Abib (2003) como atividade de demonstração. Segundo os autores essas atividades são aquelas nas quais o professor planeja e executa o experimento enquanto os alunos apenas observam os fenômenos ocorridos. Estas geralmente são utilizadas para ilustrar alguns aspectos dos conteúdos abordados em aula, tornando-os mais perceptíveis aos alunos e, dessa forma, criando condições que contribuam para seu aprendizado. São frequentemente integradas às aulas expositivas, sendo realizadas no seu início, como forma de despertar o interesse do aluno para o tema abordado, ou término da aula, como forma de relembrar os conteúdos apresentados.

Segundo Gaspar e Monteiro (2005) a utilização de atividades experimentais de demonstração, em alguns casos, são até mesmo recomendadas, especialmente quando existem poucos recursos materiais, impossibilitando que vários grupos possam realizar o experimento; quando não se dispõe de um espaço apropriado em que todos os alunos possam participar da execução de um determinado tipo de experimento; ou quando o professor dispõe de pouco tempo para a realização de experimentos, podendo incluí-los no contexto da aula expositiva. 
Foi possível perceber que a proposta deste experimento facilitou aos alunos o entendimento quanto ao processo osmótico em células vegetais. A atividade prática trouxe um significado à teoria estudada, pois os alunos conseguiram visualizar os termos e conceitos empregados no conteúdo. Isto ficou evidente na breve explicação dada pelos alunos aos bolsistas de ID. Ressalta-se também que durante a realização da atividade prática foi observado uma participação ativa e entusiasmada dos discentes o que leva a considerar a atividade como sendo motivadora no processo de ensino e aprendizagem.

Com esta prática os alunos conseguiram visualizar termos e conceitos antes vistos na teoria. A realização de experimentos segundo Bizzo (2002) é uma excelente ferramenta para o aluno concretizar o conteúdo estabelecendo relação entre teoria e prática.

\subsubsection{Protótipo de célula animal}

Esta atividade consistiu na construção de um modelo didático, um protótipo de célula animal com materiais recicláveis e de baixo custo. Foram utilizados copos plásticos descartáveis, papel ofício, papel madeira, papel cartão e garrafinha pet de iogurte.

Com livros didáticos em mãos os alunos acompanharam a explanação do professor sobre célula animal e em seguida foram instruídos pelo mesmo a construírem uma célula com suas organelas (Figura 5). Os bolsistas de ID orientaram os alunos para que cada um exercesse uma tarefa na realização desta atividade que teve a duração de duas horas/aula.

Figura 5 - Construção de organela da célula animal.

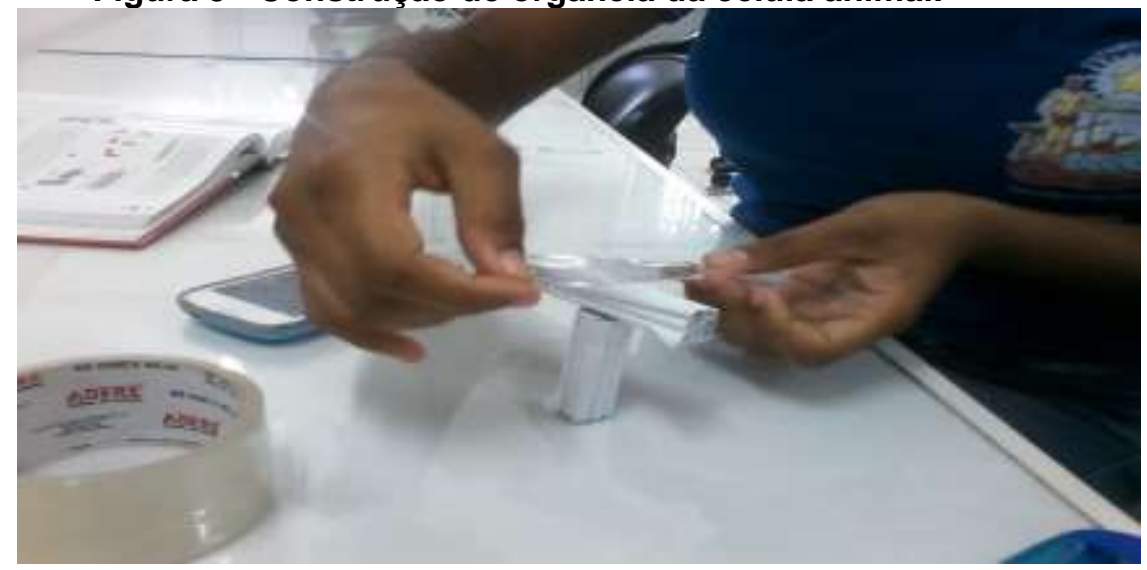

Fonte: Dados da pesquisa

Para construir o modelo didático os alunos retomaram os conceitos abordados na explanação do professor, mediante o livro didático. Isto auxiliou a confecção de cada estrutura celular. 
Com o auxílio de um grampeador os alunos foram unindo um copo ao outro, formando uma circunferência para representar a membrana plasmática (Figura 6). Foi usado papel celofane transparente para representar o citoplasma e uma bola de isopor para o núcleo da célula. As organelas confeccionadas com papéis e garrafinha de iogurte foram coloridas com tintas e lápis (Figura 7).

Figura 6 - Construção da membrana plasmática.

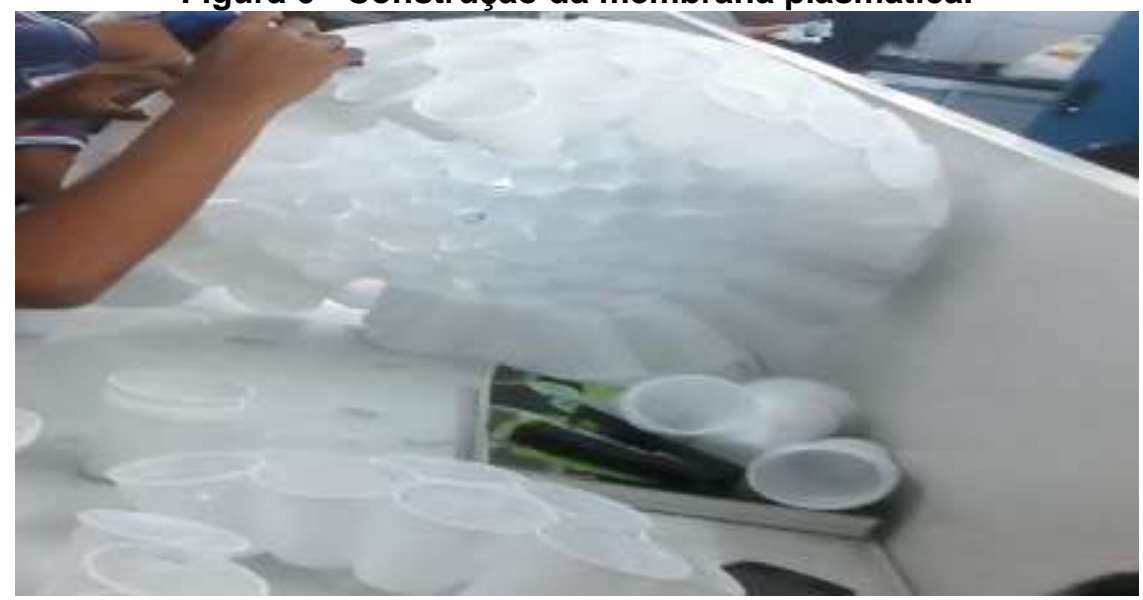

Fonte: Dados da pesquisa

Figura 7 - Protótipo de célula animal.

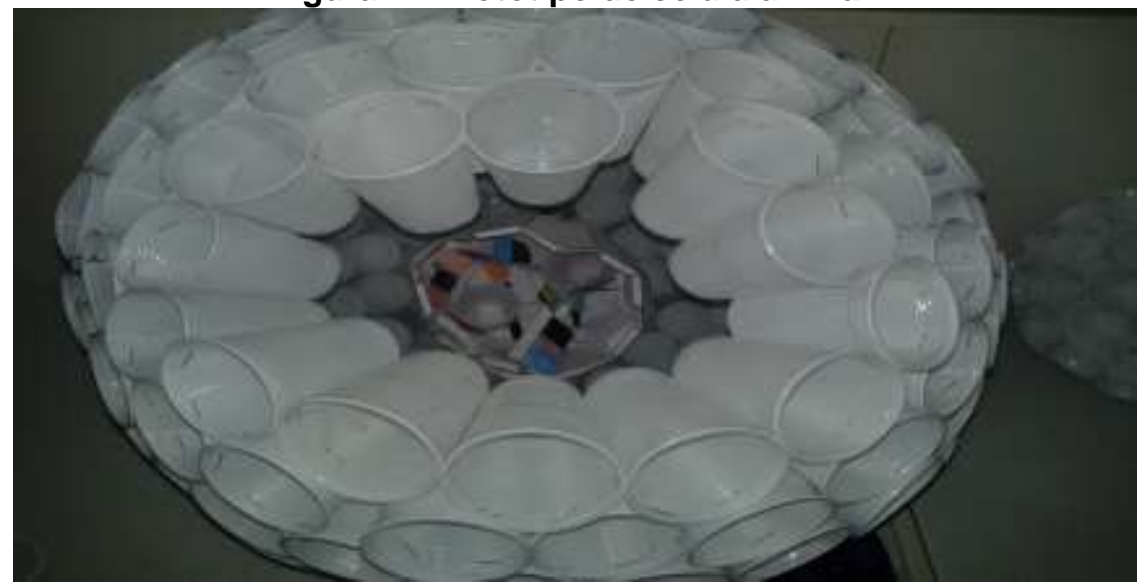

Fonte: Dados da pesquisa

Ao final da construção do protótipo da célula o professor supervisor solicitou aos alunos que citassem a função das organelas representadas. Feito isto cada qual pôde falar sobre o que construiu ou representou.

Foi possível perceber a interação entre os alunos, envolvidos e interessados pelo conteúdo de forma participativa durante o desenvolvimento da atividade, que serviu para exercitar a habilidade na confecção do modelo didático. De acordo Kierepka, Gullich e Hermel (2015), os modelos quando construídos pelos próprios alunos possibilitam a construção do conhecimento sobre o estudo da célula, facilitando a aprendizagem, por se constituírem autores do processo. 


\subsubsection{Sequência Didática: Divisão celular}

Uma Sequência Didática (SD) foi proposta objetivando o conhecimento para identificação das fases do processo de divisão celular: Mitose e Meiose. A SD foi constituída de três etapas:

\section{I- Exploração do conceito}

Inicialmente o professor fez uma explanação do assunto de forma resumida, explicando a importância da divisão celular e como seria o desenvolvimento da SD.

Alguns tablets foram disponibilizados pelo professor aos alunos, para acessarem o endereço de um vídeo ilustrativo onde demonstrava as fases da Mitose, porém os mesmos não estavam devidamente formatados e isso inviabilizou o uso pelos alunos. Diante disto, o professor supervisor utilizou o seu próprio notebook e durante a exibição do vídeo foi explicando o que ocorria nas fases da Mitose. Após isso, foi entregue aos alunos um material confeccionado pelos bolsistas de ID, onde constavam imagens e definições em recortes de cartolina para que eles relacionassem imagens às definições correspondentes às fases da Mitose, iniciando-se pela prófase e finalizando com telófase (Figura 8).

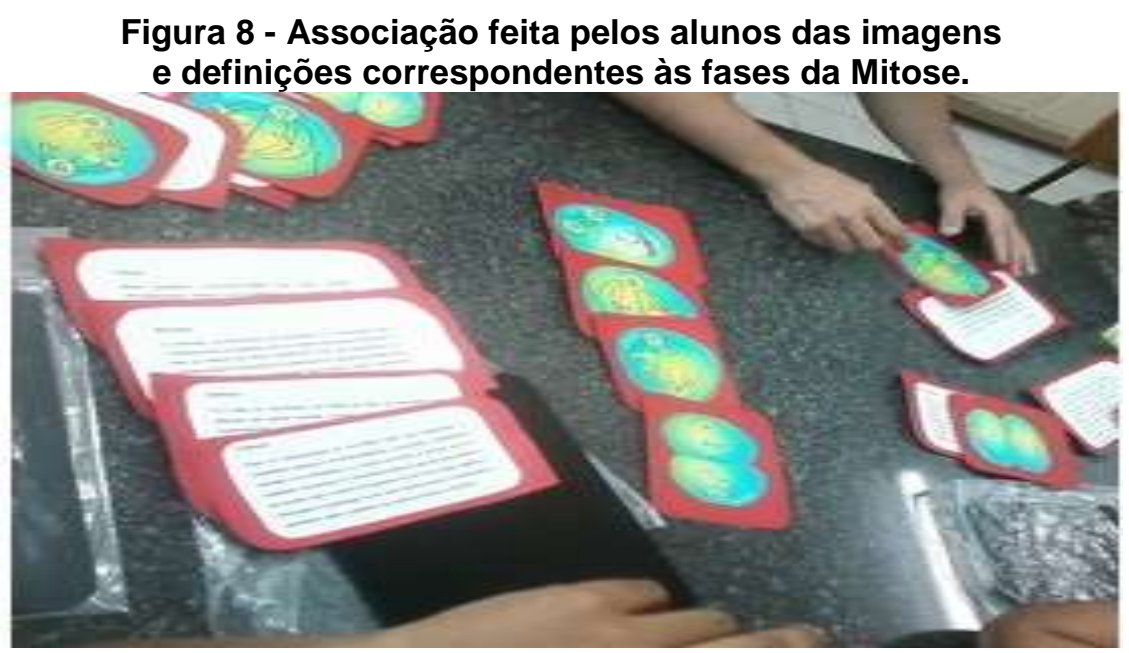

Fonte: Dados da pesquisa

II - Investigação do conceito

Nesta etapa os alunos assistiram a um vídeo sobre Meiose e logo depois receberam do professor uma folha contendo três situações problemas relacionadas à divisão celular para que pudessem resolver. 
III - Solução de problemas

O professor expôs em uma TV, imagens relacionadas ao cariótipo humano e realizou breve explicação sobre o mesmo. Em seguida distribuiu aos alunos imagens impressas de cromossomos do cariótipo humano para que cada aluno realizasse a representação de células haploides e diploides conforme fossem solicitadas pelo professor. Feito isto os alunos socializaram suas representações.

Esta atividade durou cerca de três horas/aula. A primeira etapa foi bastante tranquila e encarada com facilidade pelos alunos, com participação interativa. Na segunda etapa, eles se apresentaram inicialmente recatados pelo fato de ter que resolver as situações problema, porém a medida que as bolsistas de ID auxiliavam na leitura, direcionando a interpretação, os alunos interagiam respondendo. O mesmo aconteceu na terceira etapa, onde bolsistas de ID e o professor buscaram incentivar a turma para representarem o que fora solicitado. Os alunos foram avaliados pela observação a partir do desempenho da atividade.

Esta atividade foi de suma importância, visto que englobou investigação e experimentação numa prática dinâmica, promovendo a interação dos alunos com o conteúdo, aguçando a interpretação. De acordo Dolz, Noverraz e Schneuwly (2004) e Silva e Bejarano (2013) as sequencias didáticas oferecem e desenvolvem nos alunos práticas de linguagens e instrumentos que desenvolvam suas capacidades de expressão oral e escrita em diversas situações de comunicação, uma vez que estas são um conjunto de atividades escolares organizadas, de maneira sistemática, em torno de um gênero textual oral ou escrito, permitindo a elaboração de contexto de produção de forma precisa, por meio de atividades e exercícios múltiplos e variados.

\subsubsection{Revisão com questões de Vestibulares e ENEM}

Visando revisar e discutir os conteúdos vistos no $1^{\circ}$ semestre do ano letivo, foram selecionadas pelas bolsistas de ID 14 questões objetivas de provas de Vestibulares e Exame Nacional do Ensino Médio (ENEM). Foi feito um slide com as questões selecionadas e com o auxílio do retroprojetor multimídia foi feita a apresentação do mesmo aos alunos na sala de projeção do colégio. A dinâmica da atividade ocorreu em duas horas/aula.

Inicialmente foi feita a exibição de um vídeo motivacional com relato de experiências de jovens que obtiveram êxito no ENEM. Depois, cada bolsista lia uma questão e 
incentivava os alunos a interpretar e responder com atenção. Logo na primeira questão lida eles pareciam meio retraídos, talvez com receio de errarem a resposta.

Sugerimos que para resolução das questões, eliminassem questões que eles julgassem estar incorretas. Isto facilitaria descobrir entre as prováveis questões corretas qual de fato era a correta.

Foi possível com esta atividade testar o grau de fixação dos conteúdos abordados no $1^{\circ}$ semestre letivo e deixar os alunos familiarizados com os tipos de questões aplicadas nos Vestibulares e no ENEM, pois em breve eles estariam prestando um dos modelos de provas. Ressalta-se que outro fato importante foi estimular habilidades de leitura e interpretação das questões.

Os resultados encontrados evidenciam a importância desse tipo de atividade, pois as mesmas levam os alunos a indagação dos conteúdos, leitura e interpretação de textos (GONÇALVES, 2010) e a familiarização com esse tipo de questões, tendo em vista que muito em breve estes alunos estarão prestando esse tipo de exame.

\section{CONSIDERAÇÕES FINAIS}

As formas diferenciadas de lidar com os conteúdos por meio das atividades práticas, desenvolvidas pelo subprojeto de Biologia, proporcionaram aos alunos de $1^{\circ}$ ano do ensino médio do Colégio Estadual Alfredo Dutra a apropriação dos conteúdos relacionando teoria e prática e contribuiu para que houvesse o melhor aprendizado.

Com objetivos diferentes as intervenções didáticas estimularam a interação dos alunos com os diferentes conteúdos abordados, deixando de lado a passividade das aulas expositivas, ultrapassando assim o ensino tradicional que impossibilita os alunos de construírem seu conhecimento.

Pode-se afirmar que o PIBID é um instrumento eficiente que elenca a diversificação de atividades que estimulam as diferentes habilidades e capacidades dos alunos, tornandoos sujeitos ativos no processo de ensino e aprendizagem. O dinamismo que o PIBID trouxe às atividades propostas deu um suporte ao ensino dos conteúdos abordados e foi relevante para o desenvolvimento de aulas mais interativas que promoveram a construção do conhecimento. Ressalta-se a importância do PIBID tanto para os alunos quanto para 0 professor regente e os bolsistas de ID, pois houve articulação de várias faces do ensino e da aprendizagem a partir da investigação, experimentação, construção de modelos didáticos e sequência didática. 


\section{AGRADECIMENTOS}

Os autores agradecem a Universidade Estadual do Sudoeste da Bahia/Campus de Itapetinga-BA pelo apoio institucional; a CAPES pelo fomento financeiro e ao Colégio Estadual Alfredo Dutra pela parceira na realização das atividades do subprojeto de biologia do PIBID-UESB.

\section{REFERÊNCIAS}

AMORIM A. S. A influência do uso de jogos e modelos didáticos no ensino de biologia para alunos de ensino médio. Monografia [Licenciatura em Ciências Biológicas] - Universidade Aberta do Brasil. Beberibe, 2013.

ANDRADE, M. L. F.; MASSABNI, V. G. O desenvolvimento de atividades práticas na escola: um desafio para os professores de Ciências. Ciência \& Educação, v. 17, n. 4, p. 835-854, 2011.

AQUINO FILHO, G.; MACHADO, J. T.; AMARAL, L. H. Ausubel: Aprendizagem Significativa e Avaliação. Revista Atlante, São Paulo, v.10, 2015. Disponível em: < http://www.eumed.net/rev/atlante/2015/10/ausubel.html > Acesso em: 14/04/2016.

ARAÚJO, M. S. T; ABIB, M. L. V. S. Atividades Experimentais no Ensino de Física: diferentes enfoques, diferentes finalidades. Revista Brasileira de Ensino de Física, v.25, n.2, p.176-194, 2003.

AUSUBEL, D. P. Aquisição e retenção de conhecimentos: uma perspectiva cognitiva. 1 ed. Lisboa: Plátano Edições Técnicas, 2003, 219 p.

BARROS, M.D.M.; ZANELLA, P.G.; ARAÚJO-JORGE, T.C. A música pode ser uma estratégia para o ensino de ciências naturais? Analisando concepções de professores da educação básica. Revista Ensaio, v.15, n. 1, p. 81-94, 2013.

BEREZUK, P. A.; INADA, P. Avaliação dos laboratórios de ciências e biologia das escolas públicas e particulares de Maringá, Estado do Paraná. Acta Scientiarum. Human and Social Sciences, Maringá, v. 32, n. 2, p. 207-215, 2010.

BERTONCELLO, L.; SANTOS, M.R. Música aplicada ao ensino da informática em ensino profissionalizante. Iniciação Científica CESUMAR, v. 4, n.2, p. 131- 142, 2002. 
BIZZO, N. Ciências: Fácil ou difícil. São Paulo: Ática, 2002.

BRASIL. Ministério da Educação. Coordenação de Aperfeiçoamento de Pessoal de Nível Superior (Capes). Pibid - Programa Institucional de Bolsa de Iniciação à Docência. 2008. Disponível em: <http://www.capes.gov.br/educacao-basica/capespibid> Acesso em: 14/04/2016.

CAMPOS, D. B.; MELLO, R.; SILVA, M. C.; FAGUNDES, A. B.; PEREIRA, D. Aprendizagem significativa com apelo ao lúdico no ensino de química orgânica: estudo de caso. InterScience Place, v. 1, p. 241-267, 2014.

CAON, C. M. Concepções de professores sobre o ensino e a aprendizagem de ciências e de biologia. [Dissertação]. Porto Alegre: Pontifícia Universidade Católica do Rio Grande do Sul, 2005.

CAVALCANTE, D. D.; SILVA, A. de F. A. de. Modelos didáticos e professores: concepções de ensino-aprendizagem e experimentações. In: XIV Encontro Nacional de Ensino de Química, Curitiba, UFPR, Julho de 2008. Disponível em: $<$ http://www.quimica.ufpr.br/eduquim/eneq2008/resumos/R0519-1.pdf >. Acesso em: $13 / 07 / 2016$.

DOLZ, Joaquim; NOVERRAZ, Michele; SCHNEUWLY, Bernard. Sequências didáticas para o oral e a escrita: apresentação de um procedimento. In: SCHNEUWLY, Bernard; DOLZ, Joaquim. Gêneros orais e escritos na escola. Campinas, SP: Mercado das Letras, 2004, p. 95-128.

GASPAR, A.; MONTEIRO, I. C. C. Atividades experimentais de demonstração em sala de aula: uma análise segundo o referencia da teoria de Vigotsky. Investigações em Ensino de Ciências, v.10, n.2, p. 227-254, 2005.

GONÇALVES, S. Aprender a ler e compreensão do texto: processos cognitivos e estratégias de ensino. 2010. Disponível em: < http://www.rieoei.org/rie46a07.htm>. Acesso em: 21/03/16.

KIEREPKA, J. S. N.; GULLICH, R. I. C.; HERMEL, E. E. S. O ensino de biologia celular por meio da confecção de modelos didáticos. In: III CIECITEC, 2015, Santo Ângelo. Anais do III Congresso Internacional de Educação Científica e Tecnológica, 2015.

OLIVEIRA, Jane Raquel Silva. Contribuições e abordagens das atividades experimentais no ensino de ciências: reunindo elementos para a prática docente. Acta Scientiae, v. 12, n. 1, p. 139-153, 2012. 
RAUSCH, R. B.; FRANTZ, M. J. Contribuições do PIBID à formação inicial de professores na compreensão de licenciandos bolsistas. Atos de pesquisa em educação-PPGM/MEv.8, n. 2, p. 620-641, 2013.

ROSA, K.S.; MATTOS, L. Tem gente nova na escola: os benefícios do PIBID para o espaço escolar. Revista Veras, São Paulo, v. 3, n. 2, p. 160-173, Julho/Dezembro, 2013.

SILVA, E. L.; BEJARANO, N. R. R. As tendências das sequências didáticas de ensino desenvolvidas por professores em formação nas disciplinas de estágio supervisionado das Universidades Federal de Sergipe e Federal da Bahia. In: IX Congreso Internacional sobre Investigación en Didáctica de las Ciencias, nº extra, p. 1942-1948, Girona, 2013.

SILVA, E. L; MENEZES, E. M. Metodologia da pesquisa e elaboração de dissertação. 3. ed. Florianópolis: Laboratório de Ensino a Distância da UFSC, 138p. 2005.

SOUZA JUNIOR., D. R.; COELHO, G. R.. Ensino por investigação: problematizando as aprendizagens em uma atividade sobre condutividade elétrica. In: IX Encontro Nacional de Pesquisa em Educação em Ciências (IX ENPEC), 2013, Águas de Lindóia, 2013.

VIANA, B. O. S.; ALMEIDA, O. S. ; FREITAS, M. S. ; PEREIRA, N. A. Impactos do PIBID para a formação de licenciandos em ciências biológicas da UESB: um relato de experiência. Revista Ensino \& Pesquisa, v. 14, n. 01, p. 260-276, 2016. 